\title{
Milk processing as a tool to reduce cow's milk allergenicity: a mini-review
}

\author{
Guanhao Bu • Yongkang Luo • Fusheng Chen • \\ Kunlun Liu • Tingwei Zhu
}

Received: 6 August 2012 / Revised: 28 January 2013 / Accepted: 29 January 2013 /

Published online: 13 March 2013

(C) The Author(s) 2013. This article is published with open access at Springerlink.com

\begin{abstract}
Milk processing technologies for the control of cow's milk protein allergens are reviewed in this paper. Cow's milk is a high nutritious food; however, it is also one of the most common food allergens. The major allergens from cow's milk have been found to be $\beta$-lactoglobulin, $\alpha$-lactalbumin and caseins. Strategies for destroying or modifying these allergens to eliminate milk allergy are being sought by scientists all over the world. In this paper, the main processing technologies used to prevent and eliminate cow's milk allergy are presented and discussed, including heat treatment, glycation reaction, high pressure, enzymatic hydrolysis and lactic acid fermentation. Additionally, how regulating and optimizing the processing conditions can help reduce cow's milk protein allergenicity is being investigated. These strategies should provide valuable support for the development of hypoallergenic milk products in the future.
\end{abstract}

Keywords Cow's milk protein · Allergen $\cdot$ Milk processing $\cdot$ Control technologies

\section{Introduction}

Food allergy is a major public health concern worldwide. It has been estimated to affect around $1 \%$ to $2 \%$ of the adult population and $5 \%$ to $8 \%$ of children below the age of 3 (Eggesbo et al. 2001; Halmerbauer et al. 2002; Helm and Burks 2000). The most common food allergens are contained in eight foods, including cow's milk, eggs, fish, crustacean/shellfish, peanuts, soy, nuts and wheat, which account for over $90 \%$ of the occurrence of all serious allergic reactions to foods worldwide (Fritsche

G. Bu $\cdot$ F. Chen $(\bowtie) \cdot$ K. Liu $\cdot$ T. Zhu

College of Food Science and Technology, Henan University of Technology, Zhengzhou 450001, China e-mail: fushenge@yahoo.com.cn

Y. Luo

College of Food Science and Nutritional Engineering, China Agricultural University, Beijing 100083, China 
2003). Epidemiological studies have reported that cow's milk protein allergy (CMPA) was the most prevalent allergy for infants or young children, with an incidence of about $2 \%$ to $7.5 \%$ in population-based studies in different countries (Fiocchi et al. 2010).

Cow's milk proteins represent the first source of antigens encountered in large quantities in infancy (Isolauri and Turjanmaa 1996). Among these antigens, $\beta$-lactoglobulin $(\beta$-LG), $\alpha$-lactalbumin $(\alpha$-LA) and caseins are the main allergens in cow's milk; other proteins, such as bovine serum albumin (BSA) and even lactoferrin (present in trace amounts) are also potential allergens (Fritsche 2003; Sharma et al. 2001). The differences in the protein composition between cow's milk and human milk may be one of the reasons that induce cow's milk allergy of infants (Fox and McSweeney 1998). Moreover, the content of immunological materials is higher in human milk than in cow's milk, which can enhance the immune functions of infants and prevent milk allergy (El-Agamy 2007; Fox and McSweeney 1998; Guo 2001).

Cow's milk allergy is clinically an abnormal adverse reaction to cow's milk proteins regulated by immunological mechanisms. Many infants present skin, gastro-intestinal, respiratory and systemic anaphylactic symptoms of CMPA. More than two symptoms occur in the majority of infants with CMPA, and the severity of which varies from mild to life-threatening (El-Agamy 2007; Exl and Fritsche 2001). Although this allergy can be outgrown in the first year of life, $15 \%$ of the affected children remain allergic.

Current measures of prevention and management of milk allergy rely on complete elimination of milk consumption. However, complete avoidance of cow's milk proteins is difficult because they are often present in many processed foods. Moreover, the elimination of cow's milk proteins will cause a nutritional inadequacy and may influence the growth of infants and children. To date, measures of controlling milk allergy by antigen elimination have not been satisfactory. Finding new and effective processing technologies to reduce the allergen content of cow's milk is therefore important for controlling milk allergy. The purpose of this article is to discuss the processing methods currently in use to control cow's milk allergy, and consequently provide some help for the development of hypoallergenic milk products for patients with CMPA.

\section{Heat treatment}

Heating is an important process in the manufacturing of most dairy products. During the heating processes, important structural and chemical changes in proteins occur, such as denaturation, aggregation and the Maillard reaction with other molecules. These alterations may have significant impacts on the antigenicity of milk protein allergens.

Among cow's milk proteins, casein is the most heat stable; however, the globular whey proteins are heat sensitive in the order of immunoglobulins $(\mathrm{Ig})<$ bovine serum albumin (BSA) $<\beta-\mathrm{LG}<\alpha$-LA (Kleber and Hinrichs 2007). Heating milk at $120^{\circ} \mathrm{C}$ for 15 min did not affect the antigenicity of bovine casein, but BSA and Igs lose their antigenicity at 70 to 80 or $100{ }^{\circ} \mathrm{C}$ (Fiocchi et al. 1998; Hanson and Mansson 1961). Baldo (1984) found that heat treatment at 80 and $100{ }^{\circ} \mathrm{C}$ for 15 min produced a drop in the $\operatorname{IgE}$ fixation capacity with $\beta$-LG and BSA; however, no change was observed 
for $\alpha$-LA and caseins. Ehn et al. (2004) detected only a slight decrease in the IgEbinding ability of $\beta$-LG after heating $\beta$-LG solution or milk at $74{ }^{\circ} \mathrm{C}$, whereas significant decrease was found at $90{ }^{\circ} \mathrm{C}$ by enzyme-linked immunosorbent assay (ELISA) inhibition studies.

Bu et al. (2009b) studied the effects of heat treatment on the antigenicity of $\alpha$-LA and $\beta$-LG in whey protein isolate (WPI) via in vitro competitive ELISA inhibition tests with rabbit serum. They found that the antigenicity of $\alpha$-LA and $\beta-\mathrm{LG}$ increased with increasing temperature from 50 to $90{ }^{\circ} \mathrm{C}$. However, antigenicity of both proteins decreased remarkably above $90^{\circ} \mathrm{C}$. When treated at $120^{\circ} \mathrm{C}$ for $20 \mathrm{~min}$, the antigenicity of $\alpha$-LA decreased by $25 \%$ compared with the initial value of the untreated sample. The increase in whey protein antigenicity from 50 to $90{ }^{\circ} \mathrm{C}$ may be caused by exposure of allergenic epitopes buried inside the native molecule due to the unfolding of conformational structure during heat denaturation (Kleber and Hinrichs 2007). It has also been shown that heat-denatured $\beta$-LG presents some new epitopes, which is not found in the native state (Davis and Williams 1998). The antigenicity decrease at above $90{ }^{\circ} \mathrm{C}$ can be attributed to the destruction or masking of conformational epitopes exposed to the surface of the molecule by sulfhydryl/disulfide exchange and subsequent aggregation (Kleber and Hinrichs 2007). Under more severe heating conditions, the Maillard reaction may lead to loss of linear epitopes and consequently reduced antigenic response (Davis and Williams 1998; Fritsche 2003). Kleber and Hinrichs (2007) reported that the antigenicity of $\beta$-LG in skim milk and sweet whey increased with increasing heating temperature from 50 to $80{ }^{\circ} \mathrm{C}$, but declined above $90{ }^{\circ} \mathrm{C}$ with increasing heating temperature, which was determined by an indirect competitive ELISA.

In addition, the effect of heating on the allergenicity of milk proteins has been investigated in several in vivo studies. Rytkönen et al. (2002) showed that heatdenatured $\beta$-LG (heated at $90{ }^{\circ} \mathrm{C}$ for $30 \mathrm{~min}$ ) induced more intensive local immunologic reaction in the gastrointestinal mucosa of rats than native $\beta$-LG. High heat (baking) reduces the allergenicity of several food proteins, presumably by altering the conformation of heat-labile proteins and thus destroying the allergenic epitopes (Thomas et al. 2007). Nowak-Wegrzyn et al. (2008) evaluated whether patients with milk allergy can tolerate extensively heated (baked) milk products. In their study, 100 children with milk allergy underwent heated milk challenges. Sixty-eight children (68\%) tolerated the extensively heated milk, 23 reacted to the heated milk and 9 tolerated both the heated and the unheated milk. Heated milk-tolerant subjects had significantly smaller skin prick test wheals, lower milk-specific and casein specific IgE and lower IgE/IgG4 ratios to casein and $\beta$-lactoglobulin compared with the heated milk-reactive subjects.

The modification of milk protein allergens by thermal processing is influenced by many factors, including the composition of the whole milk, processing conditions, circumstances of exposure to the consumer and the genetic make-up of the individual (Davis et al. 2001). Therefore, the proper thermal processing conditions need to be controlled for developing the hypoallergenic milk products.

\section{Glycation reaction}

Conjugation with reducing sugars through the Maillard reaction is an effective means of improving the functional properties of proteins. Besides, it also seems to be a 
promising method for masking food protein allergenicity (Babiker et al. 1998; Nakamura et al. 2008; van de Lagemaat et al. 2007). The conjugation of $\beta$-LG with carboxymethyl dextran (CMD) improved emulsifying properties, enhanced thermal stability and reduced immunogenicity of this protein (Hattori et al. 1994; Nagasawa et al. 1996). Conjugation with CMD was thought to induce the exposure of hydrophobic region(s) and enhanced flexibility of $\beta-L G$ molecule, which would facilitate the interaction with oleic acid at the time of emulsification, thus the emulsifying activity of $\beta$-LG at neutral $\mathrm{pH}$ was much improved by conjugation with CMD (Hattori et al. 1994). Hattori et al. (2004) also found that $\beta$-LG-acidic oligosaccharide conjugates exhibited enhanced thermal stability and reduced immunogenicity. Their findings indicated that one of the mechanisms responsible for the reduced immunogenicity was the shielding of the B cell epitopes because of the conjugation. Furthermore, another study suggested that the suppressive effect on the generation of $\mathrm{T}$ cell epitopes by conjugation with CMD played an important role in the mechanism for the reduced immunogenicity of $\beta$-LG (Kobayashi et al. 2003).

Reduction of milk protein allergenicity by the Maillard reaction depends on the amount of saccharides conjugated to proteins and the molecular weights of the saccharides. Hattori et al. (2000a) found that $\beta$-LG-CMD conjugates with higher saccharide content showed marked low immunogenicity through the evaluation of a noncompetitive ELISA using antiserum from mice. Kobayashi et al. (2001) estimated the immunogenicity of $\beta-\mathrm{LG}-\mathrm{CMD}$ conjugates with similar saccharide contents using CMD of different molecular weights. It was concluded that conjugation with CMD of higher molecular weight is effective in reducing the immunogenicity of $\beta-\mathrm{LG}$, and the masking of epitopes by CMD is responsible for the decreased immunogenicity. Similar observations were made by Hattori et al. (2000b). They prepared three $\beta$-LG-cationic saccharide conjugates using the Maillard reaction and found that conjugation with high molecular weight cationic saccharides was effective in achieving multiple functional improvements of proteins, including reduced allergenicity (Hattori et al. 2000b).

Modification in the antigenicity of milk proteins is also associated with the reaction conditions and the degree of the Maillard reaction. The effects of the Maillard reaction conditions on the antigenicity of $\beta-\mathrm{LG}$ and $\alpha$-LA in the conjugates of WPI with glucose were investigated using response surface methodology (Bu et al. 2009a, 2010a). The results showed that the conjugation of WPI with glucose effectively reduced the antigenicity of $\beta$-LG and $\alpha$-LA via the in vitro the detection of competitive ELISA with rabbit serum. This reduction of antigenicity can be controlled by regulating three independent variables (weight ratio of protein to sugar, temperature and reaction time). The model for optimal reaction conditions of a lower antigenicity of $\beta$-LG and $\alpha$-LA was established. Inhibition rates of the antigenicity of both whey proteins were over $90 \%$ under optimal reaction condition.

The allergenicity of milk proteins can be significantly reduced by conjugation with saccharides through controlled Maillard reaction. Further investigations should be conducted to elucidate the structural characteristics of conjugates and the mechanism of reduced immunogenicity. However, new epitopes may have emerged as a result of exposure of the hydrophobic region, buried in the native state because of the conjugation (Hattori et al. 2000a, b). Hattori et al. (2000b) reported that the emergence of novel immunogenicity was observed in the case of both $\beta$-LG-glucosamine ( $\beta$-LG-GlcN) 
and $\beta$-LG-chitopentaose ( $\beta$-LG-CPO). Conformational changes upon conjugation with GlcN or CPO might have induced the emergence of novel epitopes in these conjugates.

\section{High pressure}

High pressure is one of novel processing techniques in food production. Highpressure treatment can give rise to structural changes in milk proteins, such as denaturation and formation of aggregates (Iametti et al. 1997). These changes may also influence the allergenic potential of milk proteins.

Kleber et al. (2007) showed that high-pressure treatment (200 to $600 \mathrm{MPa})$ at different temperatures $\left(30-68{ }^{\circ} \mathrm{C}\right)$ could enhance the antigenicity of $\beta$-LG in the WPI-solution, sweet whey and skim milk. Another study indicated that high-pressure treatment of $\beta$-LG and WPI at 200 and $400 \mathrm{MPa}$ increased the binding to $\beta$-LGspecific rabbit IgG and did not affect the binding to $\mathrm{IgE}$ from allergic patients (Chicón et al. 2008a). The increase in antigenicity may be associated with exposure of epitopes buried in the native protein molecule and becoming accessible for the antibodies due to pressure-induced unfolding and aggregation (Kleber et al. 2007).

Meanwhile, the changes in the conformation of proteins induced by high pressure may make enzymatic digestion easier. $\beta$-lactoglobulin can be efficiently hydrolyzed by various enzymes under high pressure (Chicón et al. 2006a, 2006b). The hydrolysates obtained via the enzymatic treatment of $\beta$-LG under high pressure may exhibit reduced antigenicity and IgE binding (Bonomi et al. 2003; Fritsche 2003; Peñas et al. 2006a). The effect of high-pressure treatment (100 to $300 \mathrm{MPa})$ on the hydrolysis of dairy whey proteins by trypsin, chymotrypsin and pepsin was studied (Peñas et al. 2006a). The results indicated that high pressure enhanced whey protein hydrolysis, and reduced the residual antigenicity of the hydrolysates, depending upon the choice of enzymes. An important decrease in immunoreactivity was found for pepsin and trypsin hydrolysates obtained under high pressure (200 or $300 \mathrm{MPa}$ ) compared with enzymatic treatment alone. Another study showed that the antigenicity of bovine whey protein hydrolysates obtained with Corolase PN-L and Neutrase was significantly reduced when combined with high-pressure treatment $(300 \mathrm{MPa})$ prior to or during enzymatic hydrolysis, respectively (Peñas et al. 2006b).

Recently, López-Expósito et al. (2012) evaluated the in vivo allergenicity of $\beta$-LG hydrolysates obtained with chymotrypsin under atmospheric pressure or high-pressure conditions using a $\beta$-LG allergy mouse model. They showed that the tested hydrolysates lost allergenicity, as revealed by the absence of anaphylactic symptoms and a decrease in body temperature. In addition, they demonstrated that the peptides present in the hydrolysates lost their ability to cross-link 2 human $\operatorname{IgE}$ antibodies to induce mast cell degranulation, indicating that most of the peptides formed retained only one relevant IgE-binding epitope. Other studies have also reported that application of high pressure during enzymatic hydrolysis can effectively reduce the antigenicity and serum IgEbinding properties of milk protein hydrolysates (Beran et al. 2009; Chicón et al. 2008b; Peñas et al. 2006a, c). This reduction can be explained by an increase of accessibility of potentially immunogenic hydrophobic regions to the enzyme, thereby resulting in an improved hydrolysis (Bonomi et al. 2003). Therefore, using high pressure during 
hydrolysis of milk proteins may be an efficient strategy for producing hypoallergenic whey hydrolysates.

\section{Enzymatic hydrolysis}

Proteolysis offers an efficient way to destroy allergenic epitopes (Heyman 1999). To reduce their allergenicity, proteins can be broken down by enzyme hydrolysis into small peptide molecules and amino acids. Proteolytic enzymes are widely distributed in animal, plant and microbial organisms. Some food-grade proteinases have been used to manufacture whey protein hydrolysates with reduced antigenicity.

In the process of hydrolysis, the differences in the types of enzyme, hydrolysis model and the degree of hydrolysis may result in some discrepancies in peptide composition and residual antigenicity of the hydrolysate, as well as the taste. Pahud et al. (1985) indicated that the antigenicity of whey protein can be decreased by hydrolysis with trypsin. Nakamura et al. (1993) showed that using papain and neutrase or alcalase, protease $\mathrm{S}$, proleathe combination in hydrolysis was more effective in reducing the allergenicity of whey protein compared with single enzyme. In another study, the 'two-step' alcalase-papain hydrolysis process was the most effective in reducing the immunoreactivity of cows' milk whey protein although allergenic epitopes were still present. Addition of papain to whey protein concentrate (WPC) hydrolysates prepared with alcalase improved the sensory properties of the product obtained, especially reduced bitterness (Wróblewska et al. 2004). In addition, the antigenicity of WPC hydrolysates obtained with Alcalase can be effectively reduced by optimizing the hydrolysis conditions ( $\mathrm{pH}$, temperature and enzyme-tosubstrate ratio) (Zheng et al. 2008).

The enzymatic digestion of protein may generate new antigenic substances. Haddad et al. (1979) detected serum IgE from allergic patients using radioallergosorbent tests with a total tryptic hydrolysate of $\beta$-LG even when no IgE response could be detected with native $\beta$-LG. Schmidt et al. (1995) determined the degree of hydrolysis by pepsin of bovine $\alpha$-LA, $\beta$-LG, BSA and bovine immunoglobulin $\mathrm{G}(\mathrm{B}-\mathrm{IgG})$ in the $\mathrm{pH}$ range $2-$ 4 as well as the antigenic properties of the resulting hydrolysates. No differences were found in the antigenic properties of the hydrolysates at $\mathrm{pH} 2$ or 3, however, at $\mathrm{pH} 4 \mathrm{a}$ decrease in pepsin hydrolysis resulted in enhancement of antigenicity of all proteins except $\beta$-LG. Ena et al. (1995) showed that enzymatic proteolysis may also increase protein antigenicity by exposing more antigenic sites during hydrolysis with Corolase 7092 as observed for BSA and B-IgG. In another study (Selo et al. 1999), it was shown that tryptic hydrolysis retained and even enhanced the allergenicity of $\beta-\mathrm{LG}$, because the derived peptides were capable of a specificity to bind human IgE by ELISA assays. Their results also indicated that numerous epitopes are widely scattered all along the $\beta$-LG molecule. They may be located in hydrophobic parts of the molecule, inaccessible for IgE antibodies in the native conformation of the protein but become bio-available after digestive processes (Selo et al. 1999).

The molecular weight of the peptides obtained after hydrolysis is often analyzed for investigating the residual allergenicity. The allergenicity of peptides of molecular weight 3,000-5,000 Da has been described by Van Beresteijn et al. (1994). For peptides of molecular weight smaller than 3,000 Da, there is no agreement about 
their allergenic character. The components of the whey in the hypoallergenic formulas (HF) were fractioned according to their molecular weight and analyzed by an enzyme-linked immunoaffinity chromatography method, showing that peptides of molecular weight less than 3,000 Da were antigenic and are probably allergenic (Puerta et al. 2006). Van Beresteijn et al. (1994) showed that the 3,000 Da permeate of a Corolase 7092 WPC hydrolysate did not elicit an IgE-mediated allergic reaction. Van Hoeyveld et al. (1998) reported that an ultrafiltrated whey hydrolysate was fractionated in different molecular weight fractions using fast protein liquid chromatography. In addition, peptides with molecular masses above 2,600 Da elicited a clearly positive skin response and inhibited IgE-binding, whereas peptides below 1,400 $\mathrm{Da}$ did not provoke any positive skin response, but were still able to partly inhibit IgE-binding to the hydrolysate. In another study (Calvo and Gómez 2002), peptides of molecular weight $500 \mathrm{Da}$ of two HF reacted with the sera of babies allergic to milk proteins by immunodotting assays. The disagreement found in the literature may be due to the hydrolysis process of proteins used, and to the sensitivity of the patient against the allergen (Puerta et al. 2006).

Other studies indicated that the specificity of enzyme, rather than the degree of hydrolysis or molecular mass distribution of hydrolysates, determines the residual antigenicity of whey protein (Ena et al. 1995; Svenning et al. 2000). Ena et al. (1995) found that a filter with molecular mass cut-off 3,000 Da decreased residual antigenicity of the Corolase 7092 WPC hydrolysate, but had little effect on the pepsin/carolase PP hydrolysate. Peptides still have allergenicity if epitopes exist, although their molecular masses may be very low (Wal 2001). This result suggests that it is crucial to choose the appropriate enzyme having specificities in antigenic epitopes to effectively decrease the allergenicity of proteins.

It has been shown that combining of enzymatic hydrolysis with preceding heat treatment considerably enhanced the tryptic and peptic hydrolysis of the major milk protein $(\alpha-\mathrm{LA}$ and $\beta-\mathrm{LG})$ and thereby reduced the allergenicity of milk (Bertrand-Harb et al. 2002; Peyron et al. 2006). This result can be explained by the possible exposure of cleavage sites resulting from thermal denaturation and the increase in the susceptibility of protein to proteolysis. In addition, application of microwaves combined with enzymatic hydrolysis has been reported in several studies (El Mecherfi et al. 2011; Izquierdo et al. 2007, 2008). El Mecherfi et al. (2011) investigated the effect of combined microwave and enzymatic hydrolysis on the human immunoglobulin E ( IgE)-binding properties of $\beta$-lactoglobulin and bovine whey proteins. They found that microwave treatment enhanced the hydrolysis rates of $\beta$-lactoglobulin and bovine whey proteins compared with the same proteolytic treatment realized under conventional heating. Microwave treatment at $200 \mathrm{~W}$ enhanced the hydrolysis of $\beta$-lactoglobulin by pepsin in $3 \mathrm{~min}$ and significantly decreased its immunoreactivity.

Whey proteins and peptides derived from the enzymatic proteolysis of whey proteins can modulate a variety of immune functions, including lymphocyte activation and proliferation, cytokine secretion, antibody production, phagocytic activity, and granulocyte and natural killer cell activity (Gauthier et al. 2006; Saint-Sauveur et al. 2008). Duan et al. (2012) reported that mice sensitized by tryptic hydrolysates of $\beta$-LG showed a significantly lower spleen lymphocyte proliferation level than intact $\beta$-LG. Moreover, the hydrolysates of $\beta$-LG significantly up-regulated IFN- $\gamma$ and IL-10 production and down-regulated IL-4 and IL-5 secretions by murine splenocytes. These results suggested 
that the enzymatic hydrolysis could partly reduce the allergenicity of $\beta$-LG. Prioult et al. (2005) studied the allergenicity of acidic peptides from bovine $\beta$-LG by hydrolysis with Bifidobacterium lactis NCC362 enzymes, and their results indicated that the peptide fragments significantly up-regulated IFN- $\gamma$ and IL-10 production and down-regulated IL-4 secretion by murine splenocytes. The $\beta$-LG-derived peptides released after $B$. lactis hydrolysis could therefore be used as supplement in hypoallergenic infant formulas to stimulate oral tolerance induction to $\beta-\mathrm{LG}$ in babies at risk of allergy.

The hydrolysate formula was developed to reduce the allergenicity of cow's milk proteins. The first of the partially/moderately hydrolyzed formulae (Beba HA, Good Start, NAN HA, Nestlé) was introduced in 1985 (Exl 2001). To date, many hypoallergenic formulas are available on the market in the form of partially and extensively hydrolyzed whey or casein, as well as amino acid-derived preparations. The extensively hydrolyzed casein-based formula can be safely used for feeding children with IgE-mediated cow's milk allergy (Terheggen-Lagro et al. 2002). According to the results of a randomized controlled study, only an extensively hydrolyzed formula, and not a partially hydrolyzed formula, significantly decreased the prevalence of cow's milk allergy (Businco et al. 1999). However, partially hydrolyzed formulas may be useful in the primary prevention of cow's milk allergy in high-risk infants (Chan et al. 2002) because their taste and nutritional value may be better than those of an extensively hydrolyzed formula (Blecker 1997; Exl 2001).

\section{Lactic acid fermentation}

Proteolytic enzymes can be produced during fermentation by lactic acid bacteria (LAB). The proteolytic systems of LAB are complex and are composed of proteinases, peptidases and transport systems (El-Ghaish et al. 2011a). The hydrolysis of milk proteins by Lactobacillus fermentation may have important effects on milk digestibility and the production of bioactive peptides. Proteolysis can cause some epitopes to break and may decrease milk allergenicity (Bertrand-Harb et al. 2003; Cross et al. 2001). Moreover, probiotics have beneficial effects on immune-mediated diseases, including stimulating the immune system and decreasing the prevalence of atopy (Cross et al. 2001; Kalliomäki et al. 2003). Clinical reports have suggested that dietary consumption of fermented foods, such as yogurt, can alleviate some of the symptoms of atopy and might also reduce the development of allergies, possibly via a mechanism of immune regulation. Controlled studies indicated that consumption of fermented milk cultures containing LAB can enhance production of Type I and Type II interferons at the systemic level (Cross et al. 2001). Probiotic bacteria such as Lactobacillus GG may promote endogenous barrier mechanisms in patients with atopic dermatitis and food allergy, and may act as a useful tool in the treatment of food allergy by alleviating intestinal inflammation (Majamaa and Isolauri 1997).

Many studies have demonstrated that Lactobacillus fermentation can induce degradation of milk allergens. Twenty-one Lactobacillus strains from traditional Bulgarian yogurts have been reported to display different proteolytic activities toward $\alpha$-LA and $\beta$-LG based on electrophoresis and RP-HPLC analysis (Tzvetkova et al. 2007). Phromraksa et al. (2008) identified nine proteolytic bacteria from Thai traditional fermented foods, and found that the concentrated crude enzyme of Bacillus 
subtilis DB can digest $\beta$-LG and reduce the allergenicity of $\beta$-LG by means of SDSPAGE and immunoblotting analysis. Several recent studies have revealed that different LAB strains can reduce the antigenic properties of milk proteins. Pescuma et al. (2011) showed that Lactobacillus delbrueckii subsp. bulgaricus CRL 656 degraded pure $\beta$-LG and its epitopes, thus reducing their recognition by the IgE of allergic children using ELISA competitive test. Similarly, IgE binding of $\alpha_{\mathrm{S} 1}$-casein and $\beta$-casein can be significantly reduced by proteolytic activity of Lactobacillus fermentum IFO3956 and Lactobacillus helveticus A75 (El-Ghaish et al. 2011b; Ahmadova et al. 2012).

Changes of milk protein antigenicity and allergenicity depend on the species of LAB and conditions of fermentation. Kleber et al. (2006) found that lactic acid fermentation can attenuate $\beta$-LG antigenicity in skim milk and sweet whey. More than $70 \%$ and $90 \%$ reduction in antigenicity of sweet whey and skim milk, respectively, compared with untreated samples were detected. Synergism in the reduction of the antigenicity was observed using 1:1 mixtures of lactic acid bacteria with Streptococcus thermophilus subsp. salivarius strains. Bu et al. (2010b) indicated that the fermentation with lactic acid bacteria can significantly reduce the antigenicity of $\alpha$-LA and $\beta$-LG in skim milk by the indirect competitive ELISA using rabbit serum. Combined strains of $L$. helveticus and $S$. thermophilus were the most effective in reducing the antigenicity of $\alpha$-LA (inhibition rate $87 \%$ ) and $\beta$-LG (inhibition rate 95\%). Jedrychowski and Wroblewska (1999) reported that antigenicity of whey proteins in sterilized cow's milk was reduced by over $99 \%$ compared with raw milk after fermentation with selected LAB. However, their allergenicity in skin tests was not eliminated, only slightly attenuate. In another study (Ehn et al. 2005), fermentation with lactobacilli did not give a significant decrease in the IgE binding ability, even though chromatography data showed a gradual degradation of $\beta$-LG. This suggests that the extracellular proteolytic activity in the fermentation process did not extensively degrade the IgE epitopes. The degradation might only be partial, leaving peptides long enough to bind the antibodies. It is also possible that there is a greater access to some buried epitopes (Ehn et al. 2005).

The reduction in antigenicity suggested that during the fermentation process, some epitopes of milk proteins were destroyed because of the hydrolysis of proteolytic enzymes from Lactobacillus. The difference of antigenicity reduction from the aforementioned studies may be due to the diversity in the hydrolytic ability and the specificity of the proteinases from different LAB strains. These results are very useful for the preparation of new fermented milk products with reduced antigenic properties.

\section{Conclusions}

Cow's milk is a high nutritious food, especially for infants. However, cow's milk proteins are also a major food allergen, and tend to induce allergic reactions in infants. Prevention of milk allergy is an urgent problem all over the world and needs to be resolved through combined efforts of nutritionists, food scientists and physicians. Some processing technologies (glycation, enzymatic hydrolysis and lactic acid fermentation) can be used to effectively reduce the allergenicity of milk proteins by controlling and optimizing the processing conditions. However, a combination of different technologies may be crucial for reducing cow's milk allergy. Considering the risk of appearance of 
some new epitopes during processing, attention should be paid during modification of milk proteins. Moreover, animal and human tests should be carried out to further detect the residual allergenicity of proteins and ensure the edible safety of milk products obtained by processing technologies in the future. These strategies should provide valuable support for the development of the hypoallergenic milk products.

Acknowledgment This work was supported financially by the National Natural Science Foundation of China (award nr 31201293, 30471224 and 30871817) and National Science and Technology Ministry of China (award nr 2006BAD27B04 and 2006BAD04A06).

Open Access This article is distributed under the terms of the Creative Commons Attribution License which permits any use, distribution, and reproduction in any medium, provided the original author(s) and the source are credited.

\section{References}

Ahmadova A, El-Ghaish S, Choiset Y, Rabesona H, Drouet M, Chobert J-M, Kuliev AA, Haertlé T (2012) Modification of $\operatorname{IgE}$ binding to $\beta$ - and $\alpha_{\mathrm{S} 1 \text {-caseins by proteolytic activity of Lactobacillus helveticus }}$ A75. J Food Biochem. doi:10.11/j.1745-4514.2012.00664.x

Babiker E, Hiroyuki A, Matsudomi N, Iwata H, Ogawa T, Bando N, Kato A (1998) Effect of polysaccharide conjugation or transglutaminase treatment on the allergenicity and functional properties of soy protein. $\mathrm{J}$ Agric Food Chem 46:866-871

Baldo BA (1984) Milk allergies. Aust J Dairy Technol 39:120-128

Beran M, Klubal R, Molik P, Strohalm J, Urban M, Klaudyova AA, Prajzlerova K (2009) Influence of highhydrostatic pressure on tryptic and chymotryptic hydrolysis of milk proteins. High Press Res 29:23-27

Bertrand-Harb C, Baday A, Dalgalarrondo M, Chobert J-M, Haertlé T (2002) Thermal modifications of structure and codenaturation of $\alpha$-lactalbumin and $\beta$-lactoglobulin induce changes of solubility and susceptibility to proteases. Nahrung 46:283-289

Bertrand-Harb C, Ivanova IV, Dalgalarrondo M, Haertlé T (2003) Evolution of $\beta$-lactoglobulin and $\alpha$ lactalbumin content during yoghurt fermentation. Int Dairy J 13:39-45

Blecker U (1997) Role of hydrolyzed formulas in nutritional allergy prevention in infants. South Med J 90:1170-1175

Bonomi F, Fiocchi A, Frøkiaer H, Gaiaschi A, Iametti S, Poiesi C, Rasmussen P, Restani P, Rovere P (2003) Reduction of immunoreactivity of bovine beta-lactoglobulin upon combined physical and proteolytic treatment. J Dairy Res 70:51-59

Bu GH, Lu J, Zheng Z, Luo YK (2009a) Influence of Maillard reaction conditions on the antigenicity of bovine $\alpha$-lactalbumin using response surface methodology. J Sci Food Agric 89:2428-2434

Bu GH, Luo YK, Zheng Z, Zheng H (2009b) Effect of heat treatment on the antigenicity of bovine $\alpha$-lactalbumin and $\beta$-lactoglobulin in whey protein isolate. Food Agric Immunol 20:195-206

Bu GH, Luo YK, Lu J, Zhang Y (2010a) Reduced antigenicity of $\beta$-lactoglobulin by conjugation with glucose through controlled Maillard reaction conditions. Food Agric Immunol 21:143-156

Bu GH, Luo YK, Zhang Y, Chen FS (2010b) Effects of fermentation by lactic acid bacteria on the antigenicity of bovine whey proteins. J Sci Food Agric 90:2015-2020

Businco L, Bruno G, Giampietro PG (1999) Prevention and management of food allergy. Acta Paediatr Suppl 88:104-109

Calvo MM, Gómez R (2002) Peptidic profile, molecular mass distribution and immunological properties of commercial hypoallergenic infant formulas. Milchwissenschaft 57:187-190

Chan YH, Shek LPC, Aw M, Quak SH, Lee BW (2002) Use of hypoallergenic formula in the prevention of atopic disease among Asian children. J Paediatr Child Health 38:84-88

Chicón R, Belloque J, Recio I, López-Fandiño R (2006a) Influence of high hydrostatic pressure on the proteolysis pattern of beta-lactoglobulin A treated with trypsin. J Dairy Res 73:121-128

Chicón R, López-Fandiño R, Quirós A, Belloque J (2006b) Changes of chymotrypsin hydrolysis of betalactoblobulin A induced by high hydrostatic pressure. J Agric Food Chem 54:2333-2341 
Chicón R, Belloque J, Alonso E, López-Fandiño R (2008a) Immunoreactivity and digestibility of highpressure-treated whey proteins. Int Dairy J 18:367-376

Chicón R, López-Fandiño R, Alonso E, Belloque J (2008b) Proteolytic pattern, antigenicity, and serum immunoglobulin $\mathrm{E}$ binding of $\beta$-lactoglobulin hydrolysates obtained by pepsin and high-pressure treatments. J Dairy Sci 91:928-938

Cross ML, Stevenson LM, Gill HS (2001) Anti-allergy properties of fermented foods: an important immunoregulatory mechanism of lactic acid bacteria? Int Immunopharmacol 1:891-901

Davis PJ, Williams SC (1998) Protein modification by thermal processing. Allergy 53:102-105

Davis PJ, Smales CM, James DC (2001) How can thermal processing modify the antigenicity of proteins? Allergy 56:56-60

Duan CC, Huo GC, Yang LJ, Ren DX, Chen JL (2012) Comparison of sensitization between $\beta$-lactoglobulin and its hydrolysates. Asian Pac J Allergy Immunol 30:32-39

Eggesbo M, Botten G, Halvorsen R, Magnus P (2001) The prevalence of allergy to egg: a population-based study in young children. Allergy 56:403-411

Ehn BM, Ekstrand B, Bengtsson U, Ahlstedt S (2004) Modification of IgE binding during heat processing of the cow's milk allergen beta-lactoglobulin. J Agric Food Chem 52:1398-1403

Ehn BM, Allmere T, Telemo E, Bengtsson U, Ekstrand B (2005) Modification of IgE binding to $\beta$ lactoglobulin by fermentation and proteolysis of cow's milk. J Agric Food Chem 53(9):3743-3748

El Mecherfi KE, Saidi D, Kheroua O, Boudraa G, Touhami M, Rouaud O, Curet S, Choiset Y, Rabesona H, Chobert JM, Haertlé T (2011) Combined microwave and enzymatic treatments for $\beta$-lactoglobulin and bovine whey proteins and their effect on the IgE immunoreactivity. Eur Food Res Technol 233:859867

El-Agamy EI (2007) The challenge of cow milk protein allergy. Small Ruminant Res 68:64-72

El-Ghaish S, Ahmadova A, Hadji-Sfaxi I, El Mecherfi KE, Bazukyan I, Choiset Y, Rabesona H, Sitohy M, Popov YG, Kuliev AA, Mozzi F, Chobert J-M, Haertlé T (2011a) Potential use of lactic acid bacteria for reduction of allergenicity and for longer conservation of fermented foods. Trends Food Sci Tech 22:509-516

El-Ghaish S, Rabesona H, Choiset Y, Sitohy M, Haertlé T, Chobert J-M (2011b) Proteolysis by Lactobacillus fermentum IFO3956 isolated from Egyptian milk products decreases immuno-reactivity of $\alpha_{\mathrm{S} 1 \text {-casein. } \mathrm{J}}$ Dairy Res 78:203-210

Ena JM, Van Beresteijn ECH, Robben AJPM, Schmidt DG (1995) Whey protein antigenicity reduction by fungal proteinases and a pepsin/pancreatin combination. J Food Sci 60:104-110

Exl BM (2001) A review of recent developments in the use of moderately hydrolyzed whey formulae in infant nutrition. Nutr Res 21:355-379

Exl BM, Fritsche R (2001) Cow's milk protein allergy and possible means for its prevention. Nutrition 17:642-651

Fiocchi A, Restani P, Riva E, Mirri GP, Santini I, Bernardo L, Galli CL (1998) Heat treatment modifies the allergenicity of beef and bovine serum albumin. Food Technol 53:798-802

Fiocchi A, Brozek J, Schünemann H, Bahna SL, von Berg A, Beyer K, Bozzola M, Bradsher J, Compalati E, Ebisawa M, Guzman MA, Li H, Heine RG, Keith P, Lack G, Landi M, Martelli A, Rancé F, Sampson H, Stein A, Terracciano L, Vieths S (2010) World Allergy Organization (WAO) Diagnosis and Rationale for Action against Cow's Milk Allergy (DRACMA) guidelines. Pediatr Allergy Immunol 21:1-125

Fox PF, McSweeney PLH (1998) Dairy chemistry and biochemistry. Blackie Academic \& Professional, London

Fritsche R (2003) Role for technology in dairy allergy. Aust J Dairy Technol 58:89-91

Gauthier SF, Pouliot Y, Saint-Sauveur D (2006) Immunomodulatory peptides obtained by the enzymatic hydrolysis of whey proteins. Int Dairy J 16:1315-1323

Guo BH (2001) Dairy chemistry. China Light Industry Press, Beijing

Haddad ZH, Kalra V, Verma S (1979) IgE antibodies to peptic and peptic-tryptic digest of $\beta$-lactoglobulin: significance in food hypersensitivity. Ann Allergy 42:368-371

Halmerbauer G, Gartner C, Schier M, Arshad H, Dean T, Koller DY, Karmaus W, Kuehr J, Forster J, Urbanek R, Frischer T, SPACE collaborative study team (2002) Study on the prevention of allergy in children in Europe (SPACE): allergic sensitization in children at 1 year of age in a controlled trial of allergen avoidance from birth. Pediatr Allergy Immunol 13(s15):47-54

Hanson LA, Mansson I (1961) Immune electrophoretic studies of bovine milk and milk products. Acta Paediatrica 50:484-490

Hattori M, Nagasawa K, Ametani A, Kaminogawa S, Takahashi K (1994) Functional changes in $\beta$ lactoglobulin by conjugation with carboxymethyl dextran. J Agric Food Chem 42:2120-2125 
Hattori M, Nagasawa K, Ohgata K, Sone N, Fukuda A, Matsuda H, Takahashi K (2000a) Reduced immunogenicity of $\beta$-lactoglobulin by conjugation with carboxymethyl dextran. Bioconjugate Chem 11:84-93

Hattori M, Numamoto K, Kobayashi K, Takahashi K (2000b) Functional changes in $\beta$-lactoglobulin by conjugation with cationic saccharides. J Agric Food Chem 48:2050-2056

Hattori M, Miyakawa S, Ohama Y, Kawamura H, Yoshida T, To-o K, Kuriki T, Takahashi K (2004) Reduced immunogenicity of $\beta$-lactoglobulin by conjugation with acidic oligosaccharides. J Agric Food Chem 52:4546-4553

Helm RM, Burks AW (2000) Mechanisms of food allergy. Curr Opin Immunol 12:647-653

Heyman M (1999) Evaluation of the impact of food technology on the allergenicity of cow's milk proteins. Proc Nutr Soc 58:587-592

Iametti S, Transidico P, Bonomi F, Vecchio G, Pittia P, Rovere P, Dall'Aglio G (1997) Molecular modifications of $\beta$-lactoglobulin upon exposure to high pressure. J Agric Food Chem 45:23-29

Isolauri E, Turjanmaa K (1996) Combined skin prick and patch testing enhances identification of food allergy in infants with atopic dermatitis. J Allergy Clin Immunol 97:9-15

Izquierdo F, Inteaz A, Varoujan Y, Gomez R (2007) Microwave assisted digestion of $\beta$-lactoglobulin by pronase, $\alpha$-chymotrypsin and pepsin. Int Dairy J 17:465-470

Izquierdo F, Penas E, Luisa B, Gomez R (2008) Effects of combined microwave and enzymatic treatments on the hydrolysis and immunoreactivity of dairy whey proteins. Int Dairy J 18:918-922

Jedrychowski L, Wroblewska B (1999) Reduction of the antigenicity of whey proteins by lactic acid fermentation. Food Agric Immunol 11:91-99

Kalliomäki M, Salminen S, Poussa T, Arvilommi H, Isolauri E (2003) Probiotics and prevention of atopic disease: 4-year follow-up of a randomised placebo-controlled trial. Lancet 361:1869-1871

Kleber N, Hinrichs J (2007) Antigenic response of $\beta$-lactoglobulin in thermally treated bovine skim milk and sweet whey. Milchwissenschaft 62:121-124

Kleber N, Weyrich U, Hinrichs J (2006) Screening for lactic acid bacteria with potential to reduce antigenic response of $\beta$-lactoglobulin in bovine skim milk and sweet whey. Innov Food Sci Emerg Technol 7:233-238

Kleber N, Maier S, Hinrichs J (2007) Antigenic response of bovine $\beta$-lactoglobulin influenced by ultrahigh pressure treatment and temperature. Innov Food Sci Emerg Technol 8:39-45

Kobayashi K, Hirano A, Ohta A, Yoshida T, Takahashi K, Hattori M (2001) Reduced immunogenicity of $\beta$-lactoglobulin by conjugation with carboxymethyl dextran differing in molecular weight. J Agric Food Chem 49:823-831

Kobayashi K, Yoshida T, Takahashi K, Hattori M (2003) Modulation of the T cell response to $\beta$ Lactoglobulin by conjugation with carboxymethyl dextran. Bioconjug Chem 14:168-176

López-Expósito I, Chicón R, Belloque J, López-Fandiño R, Berin MC (2012) In vivo methods for testing allergenicity show that high hydrostatic pressure hydrolysates of $\beta$-lactoglobulin are immunologically inert. J Dairy Sci 95:541-548

Majamaa H, Isolauri E (1997) Probiotics: a novel approach in the management of food allergy. J Allergy Clin Immunol 99:179-185

Nagasawa K, Takahashi K, Hattori M (1996) Improved emulsifying properties of $\beta$-lactoglobulin by conjugating with carboxymethyl dextran. Food Hydrocoll 10:63-67

Nakamura T, Sado H, Syukunobe Y, Hirota T (1993) Antigenicity of whey protein hydrolysates prepared by combination of two proteases. Milchwissenschaft 48:667-670

Nakamura S, Suzuki Y, Ishikawa E, Yakushi T, Jing H, Miyamoto T, Hashizume K (2008) Reduction of in vitro allergenicity of buckwheat Fag e 1 through the Maillard-type glycosylation with polysaccharides. Food Chem 109:538-545

Nowak-Wegrzyn A, Bloom KA, Sicherer SH, Shreffler WG, Noone S, Wanich N, Sampson HA (2008) Tolerance to extensively heated milk in children with cow's milk allergy. J Allergy Clin Immunol 122 (2):342-347, 347.e1-2

Pahud JJ, Monti JC, Jost R (1985) Allergenicity of whey protein: its modification by tryptic in vitro hydrolysis of the protein. J Pediatr Gastroenterol Nutr 4:408-413

Peñas E, Préstamo G, Baeza ML, Martínez-Molero MI, Gomez R (2006a) Effects of combined high pressure and enzymatic treatments on the hydrolysis and immunoreactivity of dairy whey proteins. Int Dairy J 16:831-839

Peñas E, Restani P, Ballabio C, Préstamo G, Fiocchi A, Gomez R (2006b) Evaluation of the residual antigenicity of dairy whey hydrolysates obtained by combination of enzymatic hydrolysis and highpressure treatment. J Food Prot 69:1707-1712 
Peñas E, Snel H, Floris R, Prestamo G, Gomez R (2006c) High pressure can reduce the antigenicity of bovine whey protein hydrolysates. Int Dairy J 16:969-975

Pescuma M, Hébert EM, Rabesona H, Drouet M, Choiset Y, Haertlé T, Mozzi F, de Valdez GF, Chobert JM (2011) Proteolytic action of Lactobacillus delbrueckii subsp. bulgaricus CRL 656 reduces antigenic response to bovine $\beta$-lactoglobulin. Food Chem 127:487-492

Peyron S, Mouécoucou J, Frémont S, Sanchez C, Gontard N (2006) Effects of heat treatment and pectin addition on beta-lactoglobulin allergenicity. J Agric Food Chem 54:5643-5650

Phromraksa P, Nagano H, Boonmars T, Kamboonruang C (2008) Identification of proteolytic bacteria from Thai traditional fermented foods and their allergenic reducing potentials. J Food Sci 73:189-195

Prioult G, Pecquet S, Fliss I (2005) Allergenicity of acidic peptides from bovine $\beta$-lactoglobulin is reduced by hydrolysis with Bifidobacterium lactis NCC362 enzymes. Int Dairy J 15:439-448

Puerta A, Diez-Masa JC, de Frutos M (2006) Immunochromatographic determination of $\beta$-lactoglobulin and its antigenic peptides in hypoallergenic formulas. Int Dairy J 16:406-414

Rytkönen J, Karttunen TJ, Karttunen R, Valkonen KH, Jenmalm MC, Alatossava T, Björkstén B, Kokkonen J (2002) Effect of heat denaturation on beta-lactoglobulin-induced gastrointestinal sensitization in rats: denatured $\beta$-LG induces a more intensive local immunologic response than native $\beta$-LG. Pediatr Allergy Immunol 13:269-277

Saint-Sauveur D, Gauthier SF, Boutin Y, Montoni A (2008) Immunomodulating properties of a whey protein isolate, its enzymatic digest and peptide fractions. Int Dairy J 18:260-270

Schmidt DG, Meijer RJ, Slangen CJ, van Beresteijn EC (1995) Raising the pH of the pepsin-catalyzed hydrolysis of bovine whey proteins increases the antigenicity of the hydrolysates. Clin Exp Allergy 25 (10): 1007-1017

Selo I, Clement G, Bernard H, Chatel JM, Creminon C, Peltre G, Wal JM (1999) Allergy to bovine $\beta$ lactoglobulin: specificity of human IgE to tryptic peptides. Clin Exp Allergy 29:1055-1063

Sharma S, Kumar P, Betzel C, Singh TP (2001) Structure and function of proteins involved in milk allergies. J Chromatogr B 756:183-187

Svenning C, Brynhildsvold J, Molland T, Langsrud T, Vegarud GE (2000) Antigenic response of whey proteins and genetic variants of $\beta$-lactoglobulin-the effect of proteolysis and processing. Int Dairy $\mathrm{J}$ 10:699-711

Terheggen-Lagro SWJ, Khouw IMSL, Schaafsma A, Wauters EAK (2002) Safety of a new extensively hydrolysed formula in children with cow's milk protein allergy: a double blind crossover study. BMC Pediatr 2:10

Thomas K, Herouet-Guicheney C, Ladics G, Bannon G, Cockburn A, Crevel R, Fitzpatrick J, Mills C, Privalle L, Vieths S (2007) Evaluating the effect of food processing on the potential human allergenicity of novel proteins: international workshop report. Food Chem Toxicol 45:1116-1122

Tzvetkova I, Dalgalarrondo M, Danova S, Iliev I, Ivanova I, Chobert J-M, Haertle T (2007) Hydrolysis of major dairy proteins by lactic acid bacteria from Bulgarian yogurts. J Food Biochem 31:680-702

Van Beresteijn ECH, Peeters RA, Kaper J, Meijer RJGM, Robben AJPM, Schmidt DG (1994) Molecular mass distribution, immunological properties and nutritive value of whey protein hydrolysates. J Food Prot 57:619-625

van de Lagemaat J, Silvan JM, Moreno FJ, Olano A, del Castillo MD (2007) In vitro glycation and antigenicity of soy proteins. Food Res Int 40:153-160

Van Hoeyveld EM, Escalona-Monge M, de Swert LFA, Stevens EAM (1998) Allergenic and antigenic activity of peptide fragments in a whey hydrolysate formula. Clin Exp Allergy 28:1131-1137

Wal JM (2001) Structure and function of milk allergens. Allergy 56:35-38

Wróblewska B, Karamać M, Amarowicz R, Szymkiewicz A, Troszyńska A, Kubicka E (2004) Immunoreactive properties of peptide fractions of cow whey milk proteins after enzymatic hydrolysis. Int J Food Sci Technol 39:839-850

Zheng H, Shen XQ, Bu GH, Luo YK (2008) Effects of pH, temperature and enzyme-to-substrate ratio on the antigenicity of whey protein hydrolysates prepared by alcalase. Int Dairy J 18:1028-1033 